\title{
KOBIETA W TWÓRCZOŚCI KAROLA WOJTYŁY - JANA PAWŁA II
}

1. Obszary tematyki kobiecej. W dorobku piśmienniczym Jana Pawła II temat kobiety pojawia się w kilku wymiarach. [1] W licznych konferencjach wygłaszanych podczas środowych audiencji ogólnych, gdzie podejmuje temat metafizyki kobiety, teologii ciała, rozważanej w kontekście biblijnym i jest autorem wyrażającym te idee we wcześniejszej, jak i późniejszej twórczości literackiej. [2] W nauczaniu, związanym z praktyką duszpasterską, gdzie autor skupia się na miłości oblubieńczej, życzliwości, relacji duchowej i erotycznej, konfliktach i problemach ludzi pozostających w związkach małżeńskich, co przejawia się zarówno w podręczniku Miłość i odpowiedzialność, jak i w twórczości literackiej. [3] Sprawa kobiety zostaje naświetlona w refleksji Papieża dotyczącej postaci Najświętszej Marii Panny i w twórczości Jej poświęconej. [4] Kolejnym kobiecym ukierunkowaniem jego refleksji jest kwestia tzw. nowego feminizmu. W pewnym momencie Papież odnosi się do ideologii feministycznej, zarazem kontynuuje wczesne idee chrześcijańskiego feminizmu zapoczątkowane przed wojną przez Edytę Stein (św. Teresę Benedyktę od Krzyża). Z tych czterech obszarów w obecnym opracowaniu skupimy się na pierwszym.

2. Poezja jako przesłanie. Refleksje o poezji Jana Pawła II nie będą zawężone do kategorii filologicznych, interpretacji literackiej, poetyckiej. Rozpatrujemy poezję właśnie jako przesłanie, zasobne w sens, który nie jest tylko immanentny, nie jest też przesłaniem semper ubique, wprawdzie uniwersalnym, choć zarazem jedynie parabolicznym, ale w sens uniwersalny, a zarazem „realny”, oczywiście w realności

Dr hab. RYsZARD STRZelecki, prof. UKW - Katedra Kultury Współczesnej w Instytucie Nauk o Kulturze UKW; adres do korespondencji: Uniwersytet Kazimierza Wielkiego, ul. Jagiellońska 11, 85-067 Bydgoszcz; e-mail: rjstrzel@ukw.edu.pl. ORCID: http://orcid.org/0000-0001-8720-2526. 
transcendentnej. Toteż, zgodnie z przekonaniem Papieża, może być słowem godnym Dawcy (objawienia) przepowiadania ${ }^{1}$. Nawet w biblijnym przepowiadaniu poezja może zdziałać więcej, udźwignąć więcej, niż obarczone tym zadaniem teksty niepoetyckie. Na związek poezji K. Wojtyły z nauczaniem zwraca uwagę S. Sawicki. Autor mówi: „Twórczość Karola Wojtyły jest właściwie filozoficzną czy teologiczną medytacją. Wartością tych tekstów jest przede wszystkim myśl, a nie szczególne walory poetyckie. Natomiast myśl jest bardzo głęboka" (Sawicki 282-283). Ta uwaga usprawiedliwia sposób podejścia do poezji Jana Pawła II, którą faktycznie cechuje istotna zbieżność z innymi tekstami Autora, o charakterze teologicznym i filozoficznym, co będzie szerzej rozważane.

3. Kontekst kluczowy, autorski. W analizie poezji potrzebne jest skupienie uwagi na zasadnicznej i oczywistej spójni (jedności) twórczości literackiej z wszelkimi rozległymi obszarami dorobku Jana Pawła II, efektami jego pracy intelektualnej, duszpasterskiej czy myśli zawartej w świadectwach urzędu i charyzmatu jego osoby. Ze wskazanych wcześniej względów wypowiedzi te stanowią kontekst konieczny i w znacznej mierze wystarczający dla określenia przesłania, literackiej twórczości Autora. Kontekst z powodu rozległości dorobku Autora jest trudny do ogarnięcia, a tym bardziej wykorzystania. Wykładnia decydująca o ujęciu kobiety w persprektywie najważniejszych prawd może być jednak radykalnie ograniczona do tych tekstów, które zapewniają najgłębsze usytuowania kobiety w porządku bytowym, gdyż to one okazują się zupełnie niezbędne w analizie utworów literackich. Owe oryginalne myśli Papieża odnośnie do metafizyki i antropologii kobiety znalazły się w publikacjach z pierwszych lat pontyfikatu, później były głównie rozwijane i wielorako konstatowane.

4. Metoda. Dyskurs literacki i poetycki Jana Pawła II mieści się w tej samej wykładni myślowej, co inne teksty papieskiego nauczania. Pozwala to na wzajemne przeinterpretowywanie dokonań pisarskich Autora i na tej relacji „wewnątrz” dorobku Jana Pawła II trzeba oprzeć lekturę jego utworów. Oczywiście nie jest to jedyna perspektywa oglądu literackiego dorobku Papieża, o czym świadczy przebieg dotychczasowych badań. Jednak zasadniczo w każdej praktyce interpretacyjnej kontekstem pierwszym i podstawowym winno być nauczanie Papieża². Wskazana

\footnotetext{
${ }^{1}$ Osiąga najwyższą godność, gdy nie tylko staje się medium przepowiadania, ale w pewnych aspektach medium najdoskonalszym. Na tę godność poezji (i teatru) wskazywał już teoretyk dramatu i teatru J.J. Engel. Poezja i teatr mówią o rzeczach, których nie jest w stanie skutecznie wyrazić filozof, choć zarazem vice versa.

${ }^{2}$ Tym samym kontekst autorski stawiamy na pierwszym miejscu, a jego użycie, z uwagi na koniczność precyzji badań, określamy mianem analizy. Medytacje Jana Pawła II są poezją, cechuje je więc język poetycki, który w tradycji strukturalistycznej definiowany jest jako język o odrębnej autotelicznej konstrukcji. Pewne właściwości tego języka ujawniają się w mowie poetyckiej autora, dopełniają
} 
tu metoda, angażująca refleksję filozoficzną oraz teologiczną Papieża, wydaje się niezbędna i podstawowa.

5. Jedność tematu. Myśl Jana Pawła II w całym obszarze dokonań piśmienniczych jest oparta na tych samych pryncypiach. Przyjmujemy dość oczywiste, ale intelektualnie niełatwe założenie o jedności myślowej - jedności przesłania literackiego i wszelkich innych form twórczości Jana Pawła II. Koncepcja kobiety w istotnych dokonaniach i formach wypowiedzi nie ulega zmianie. Dotyczy to wczesnych poezji, dramatów, dotyczy rozważań, listów, autobiografii, przemówień, refleksji w czasie audiencji środowych, wreszcie dokumentów wyższej rangi, w wystąpieniach oficjalnych, adhortacjach czy encyklikach. We wszelkich tych formach zasadnicze wyróżniki tzw. geniuszu kobiecego, koncepcji kobiety są zachowane. W związku z jednością pryncypiów myślowych i rozpoznaną w dorobku Papieża jednorodną koncepcją kobiety, łatwiej postawić pytanie o wykładnię tej koncepcji oraz obraz kobiety wyłaniający się z całości dorobku. Dominujący w kulturze dzisiejszej ideał autonomii, indywidualizmu, tożsamości niezawisłej wobec jakichkolwiek determinant, zasada konstruktywizmu płci i in. przyjmuje postać powszechnie obowiązującej ideologii, wyznacza też zespół oczekiwań wobec ujmowania kobiety w pismach Jana Pawła II.

Otóż odkrywamy, że zawarte w jego pismach pojmowanie kobiety z punktu widzenia dzisiejszych ujęć ma cechy paradoksu. Ideał kobiety w kulturze ponowoczesnej zgodny z proklamacją szeroko pojmowanego feminizmu miał podnieść jej rangę, przywrócić albo zapewnić należyty status i nadać wagę bytowej odrębności. Czy tak się stało? Papież z pewnością nie podzielał przekonań i nadziei związanych z projektami feminizmu. Wyrazem jego nastawienia do całej sprawy był wspomniany chrześcijański nowy feminizm. Paradoks polegał na przeciwnym pojmowaniu godności kobiety w feminizmie i w myśli Papieża. Feminizm dotyczy społecznego i kulturowego statusu kobiety i wyrasta z przekonania o jej podrzędnej pozycji w patriarchalnie identyfikowanej kulturze. Podejście takie jest jednostronne, pomija „głębsze”, ontyczne uwarunkowania kobiety. Kategorie metafizyczne, które te ontyczne gwarancje mogłyby zapewnić, nie są jednak w feminizmie traktowane jako wyraz rzeczywistego statusu, a jedynie jako pozbawione znaczenia zachowania

\footnotetext{
i precyzują sens ujawniony w analizie kontekstowej. Poezje papieża są nienumeryczne. Występują długie wersy o charakterze medytacyjnym, niekiedy wzbogacane o składniki retoryczne. Stąd zauważane niekiedy opozycje wersów długich i bardzo krótkich, kumulujących znaczną energię ekspresji i sensu. W tej intencji prozodia wiersza ,przysłania” niekiedy, na ogół respektowany przez autora, porządek składniowy w wersach, a celem tej osobliwej delimitacji jest wyeksponowanie kluczowych treści i indywidualnego rysu autorskiego przesłania. Jest to jednak język immanentny, pozostający w tle dominującego kontekstu autorskiego. $\mathrm{Z}$ tego powodu w obecnym opracowaniu nie rozważamy jego funkcji w kształtowaniu globalnego sensu utworów.
} 
językowe, wspierające dotychczasowy stan rzeczy. Z kolei w myśli Jana Pawła II jest odwrotnie - kwestia kobiety wiąże się przede wszystkim z jej statusem osobowym i metafizycznym, a zagrożenie tego statusu w tym względzie wynika $\mathrm{z}$ feministycznej redukcji i zawężania istoty kobiety do jej miejsca w życiu codziennym, kulturowym i społecznym. Takie przeciwieństwo wypada podkreślać, mimo stosunkowo licznych wypowiedzi Papieża, które wyrażają troskę o stan kobiety, podobną do tej, jaką znaleźć można w niektórych tekstach feministycznych. Wypowiedzi te, których nie sposób tu przywoływać, wskazała i skomentowała E. Adamiak (101-105). Budząca tyle zastrzeżeń kultura tradycyjna posiadała w swoim zasobie koncepcje i instytucje zdolne ujmować bytowy status kobiety dostatecznie „głęboko”, natomiast ponowoczesność nie szuka trwałych, ontologicznych podstaw kobiecej pozycji w rzeczywistości.

6. Kobieta wobec mężczyzny. Okazuje się, że uznanie wysokiego, ontologicznego statusu kobiety łączy się w myśli Jana Pawła II z kolejnym paradoksem dla współczesnej myśli o kobiecie. Jest to paradoks bardziej jeszcze niezrozumiały i trudny do przyjęcia przez zwolenników ponowoczesnego feminizmu. Otóż kobieta osiąga swoją najwyższą rangę i osobową tożsamość nie przez przeciwstawienie wobec mężczyzny, ale w sytuacji niemal utożsamienia z nim. Papież odwołuje się tu do najstarszej historii biblijnej, poświadczonej w Ewangelii i jej filozoficznej recepcji. Znów jest to stanowisko trudne dla feminizmu, który domaga się jednoznacznego przeciwstawienia mężczyźnie, a nie gwarantowanie ontologicznej kondycji kobiety poprzez powiązanie z mężczyzną. Przyjrzyjmy się tej sprawie.

Dla określenia kobiety Autor odwołuje się do metafizycznej głębi człowieka, wskazanej w przesłaniu Księgi Rodzaju, głębia wyraża się w relacji kobiety i mężczyzny, w ich odrębności, a zarazem w nieodwołalnej i konstytutywnej jedności. W wypowiedziach Jana Pawła II - głównie tych z pierwszych lat pantyfikatu, choć również późniejszych, przejawia się to jedno, zasadnicze i źródłowe pojmowanie kobiety, wywiedzione właśnie z pierwszego rozdziału Księgi Rodzaju. Określony tam paradygmat kobiety ma swój udział w kolejnych tekstach literackich o różnym charakterze. Jak zaznaczyliśmy, poezja niemal nie dotyczy społecznego rozumienia kobiety, ale zwraca się ku jej osobowej istocie, od początku sytuuje się w kregu pryncypiów biblijnych i metafizycznych, ma swoisty „,bliźniaczy” związek z tekstami filozoficznymi i teologicznymi, co prowadzi do istotnych myślowych konsekwencji.

Idąc za tym wskazaniem, przekraczamy teorię człowieka, traktowanego w ogólności, czego domaga się filozoficzny dyskurs antropologiczny (także zgodny z wykładnią depositio fidei), a wskazujemy konstytutyw człowieka, w którym wskazane rozróżnienie: kobiety i mężczyzny i zarazem wymóg jedności są określone w najbardziej pierwotnej głębi ludzkiego bytu i w sposób najbardziej apodyktyczny. Pojmowanie odrębności bez jedności jest błędne. Istota kobiety nie jest więc równoważna 
z bytem odrębnym, nie jest nawet samym „otwarciem” na mężczyznę, ale osiąga ontyczną pełnię w byciu jednym z mężczyzną.

7. Filozofia a metafizyka biblijna. Filozofia na ogół stara się przekroczyć to zasadnicze i obligujące nas ujęcie bytu, w którym człowiek ma postać kobiety bądź mężczyzny, w stronę jakiegoś bardziej jeszcze elementarnego porządku, w którym rozróżnienia te zanikają. Czy wobec koncepcji bytowej ukształtowanej na podłożu myśli biblijnej, warto w ogóle podejmować tego typu „idealistyczną” procedurę, skoro może nas ona jedynie oddalać od bytu, a nie przybliżać? Po co to czynić? Faktycznie każda taka procedura oddala nas od całości i kompletności bytu. Są drogi, które oddalają od jakichkolwiek konstytutywów człowieka, mówię o antropologiach ponowoczesnych, ale są też drogi, które wprawdzie nie obejmują całości bytowej, prowadzą jednak do odsłonięcia istotnych konstytutywnych aspektów człowieka. I te drogi wydają się uprawnione. Mówimy tu o wielorakich nurtach myśli personalistycznej, głównie o personalizmie metafizycznym, bliskim refleksji uprawianej przez samego Jana Pawła II jeszcze przed wyborem na Stolicę Piotrową. Personalizm, istotny dla filozoficznej, osobowej wykładni człowieka, przywołujemy wszelako ze znacznym zastrzeżeniem. Wypada powtórzyć - dotyczy wprawdzie statusu człowieka, jego nieredukowalnego stanowiska pośród innych bytów, zasadniczo nie obejmuje jednak innych konstytutywnych wymiarów ludzkiego bytu, ujawnionych w egzegezie biblijnej $\mathrm{i}$ istotnych $\mathrm{w}$ interpretacji poezji.

W proklamacji bytowej pełni, do której wracamy, powraca również istotna kwestia odmienności płci, czyli stworzenia człowieka jako istoty duchowo-cielesnej mężczyzną lub kobietą. W Biblii są dwa opisy stworzenia człowieka. Opis pierwszy młodszy z tradycji kapłańskiej 1,27 i następujący po nim opis uznany za chronologicznie starszy 2,24 i in., przynależny do tradycji zwanej jahwistyczną. Jan Paweł II w teologii ciała i teologii kobiety uwzględnia obydwa opisy. Mniej istotna jest ocena ich walorów stylistycznych, historycznych czy też anachronizm wyobrażeń opisu drugiego, ważniejsza natomiast okazuje się podobna, a w istocie ta sama prawda teologiczna oraz tak samo ważny w obu opisach sens antropologiczny. Toteż obydwa stanowią istotny kontekst w interpretacji literackiej.

8. Wyróżniki teologii ciata w papieskich tekstach. Celem tej części wypowiedzi nie jest systematyczne zarysowanie treści ważnych dzieł z pierwszego okresu pontyfikatu Jana Pawła II (co zresztą byłoby niewykonalne), ale potrzeba skupienia uwagi na kilku zawartych w tych tekstach wyróżnikach teologii ciała i teologii mężczyzny i kobiety, czyli na sprawach absolutnie najważniejszych w realizacji obecnego tematu. Mowa o bezspornie najistotniejszym tomie pierwszym teologii ciała Mężczyzna i niewiasta stworzyt ich (Chrystus odwoluje się do „poczatku”), tomie czwartym, dotyczącym sakramentu małżeństwa (Sakrament) oraz wspomnianej adhortacji 
Familiaris consortio. Ważne rozwinięcie niektórych zagadnień tomu 1 zawiera list apostolski Mulieris dignitatem.

Opis pierwszy, młodszy spotyka się z aprobatą dzisiejszej teologii. Ukazuje stworzenie człowieka - kobiety i mężczyzny na podobieństwo Boga. Narzuca się w nim równoważność, a nawet równoczesność stworzenia obu postaci człowieka. Jednak w tym opisie brak wielu walorów antropologii, które ujawnia i uzupełnia dopiero starszy opis drugi. Ów drugi opis stworzenia, utworzenie kobiety z żebra Adama, jest na ogół lekceważony z powodu rzekomego anachronizmu i nadmiernej antropomorfizacji, dotyczącej także postaci Boga. Ponadto teologowie, pozbawieni należytego dystansu do postmodernizmu, dostrzegają w nim przede wszystkim przejaw patriarchalizmu. Obydwa opisy są teologicznie równowartościowe, a w dociekaniu sensu antropologicznego komplementarne, gdyż dopiero łącznie tworzą właściwy kontekst dla analizy twórczości Papieża. W obydwu rzeczywistym Stwórcą kobiety i mężczyzny jest Bóg. Opis pierwszy od razu i jednoznacznie zapewnia, oczekiwaną w aurze dzisiejszego feminizmu, równoważność pierwszej pary. Jednak dopiero opis drugi ukazuje głębię ich wzajemnej relacji. Ujawnia tożsamość, która wyraża się w ostatecznej jedności. Człowiek rozpoczyna się od jedyności, oboje pochodzą z jednego ciała. Nie chodzi o samą cielesność, wywiedzioną z „,prochu ziemi”, ale o cielesność, poprzez którą pierwsza ludzka para zyskuje wzajemną identyfikację, świadczy o tym zaimek „mojego”, „,moich”, ciało nie jest anonimowe, obojętne, ale zapewnia osobową pełnię im obojgu ${ }^{3}$.

9. Metafizyka biblijna a personalizm. Właśnie uznanie osobowej pełni w ,jednym ciele" stanowi punkt wyjścia dla, wymagającej znacznej subtelności, refleksji o relacyjnym charakterze ludzkiego bytu. Filozofia współczesna zgłębiła tę problematykę, myślenie komunikacjonistyczne, komunitarialne, dialogiczne (w filozofii spotkania), dramatyczne (w filozofii dramatu), w hermeneutyce opartej na budowaniu więzi poznawczej jako fuzji, partycypacji, komunii, a nawet ofiary. Bezspornie jednak wszystkie te perspektywy filozoficzne nie sięgają biblijnego świadectwa i metafizyki promieniującej z Księgi Rodzaju, tak znacząco wspartej słowami Chrystusa, który odwołuje się do początku. W tej wielorakiej refleksji, pomimo wnikliwego i dojrzałego pojmowania osoby, więź proklamowana między osobami jest słaba relacjonistyczna i woluntarna (liberatorianistyczna) (Chudy 69-70), bo i, oparta na tej więzi kondycja osoby, jest słaba. Nawet w personalizmie filozofii klasycznej człowiek pozostaje wprawdzie nieusuwalnie osobą, jest jednak pozbawiony wyróżników biblijnej metafizyki człowieka, tak skutecznie odsłoniętej przez Jana Pawła II.

\footnotetext{
${ }^{3}$ Papież zauważa: „Uwzględniając archaiczny sposób wyrażania myśli, sposób obrazowy i przenośny, możemy ustalić, że chodzi tutaj o jednorodność całej istoty obojga" (Mężczyzna i niewiasta stworzyt ich. Chrystus odwoluje się do ,początku” 38).
} 
Tu dopiero relacyjność nie ma charakteru sytuacyjnego, woluntarnego, ale sięga istoty bytu. Ustalenie to prowadzi do zasadniczego pytania: co wnosi ta wyjątkowa biblijna metafizyka do teologii kobiety?

10. Samotność. Zrozumienie wagi tej metafizyki wiąże się ze stanem samotności pierwszego człowieka. Bez analizy samotności nie można zrozumieć głębi późniejszej jedności. Samotność nie jest stanem emocjonalnym, społecznym czy nawet egzystencjalnym, jest stanem metafizycznym ${ }^{4}$. Zwraca na to uwagę Jan Paweł II, stąd zupełnie anachroniczne wydaje się umieszczenie samotności w relacji płci. Pierwotna samotność jest stanem człowieka jako rodzaju, a nie stanem mężczyzny, pozbawionego darowanej mu następnie kobiety. Samotność człowieka (ädāma) polega na braku istotnych relacji osobowych, w otoczeniu zwierząt, którym nadał imiona: „istota żywa”, którymi dysponował i pośród nich „pomocy nie znalazł”. Przezwyciężenie samotności możliwe jest wewnątrz, właściwej dla ludzkiego rodzaju, istności. Dokonuje się w ramach omówionej już sytuacji wzajemnej jedności pierwszej pary. W opisie drugim ukazany został porządek stwarzania człowieka, to co w pierwszym opisie zostało ujęte niejako momentalnie, w jednej syntetycznej frazie: „I stworzył Bóg ludzi na obraz swój, na obraz Boga stworzył ich, stworzył mężczyznę i kobietę" (Rdz 1,27).

11. Od samotności do jedności dwojga. Niezbędne aspekty kontekstu badawczego natrafiamy w dalszych fragmentach katechez tomu 1. Ważne jest wyjęcie żebra z ciała Adama i utworzenie kobiety (równoważnego człowieka). Samotność pojmujemy metafizycznie, ale i stan bytu przekraczającego tę samotność pojmujemy metafizycznie. Otóż istnieje właśnie różnica metafizyczna między stanem sprzed stworzenia kobiety i po jej stworzeniu. Od tego momentu człowiek jest już bądź mężczyzną (iš), bądź kobietą (išša). Słowa Papieża: „Jeśli przyjąć w dalszym ciągu znamienną różnicę słownictwa, można wnioskować, że w swój genezyjski sen zapada »człowiek « ('ādām'), aby zbudzić się z niego »mężczyzną《 i »niewiastą《" (Mężczyzna i niewiasta stworzyt ich. Chrystus odwotuje się do „poczatku”37). Został mianowicie wyposażony w ich wzajemną relację - odrębność, dającą zarazem jedność w stworzeniu i jedność jako cel wzajemnych pragnień i dążeń. Na czym polega metafizyczna doniosłość tego przejścia. Otóż wedle Papieża: „,analogia snu wskazuje tutaj nie tyle na zstępowanie ze świadomości w podświadomość ile raczej

\footnotetext{
${ }^{4}$ Filozofie współczesne, które nie podnoszą samotności i jedności do rangi konstytutywów ludzkiego istnienia, wszystkie nieuchronnie popadają w pułapkę pierwotnej samotności. Brak uwzględnienia w nich zjawiska samotności i uwalniającej od niej jedności, sprawia, że dopiero metafizyka biblijna (Księgi Rodzaju) okazuje się refleksją sytuującą człowieka we właściwym stanie bytu (poczynając od słów Boga: „Niedobrze, by człowiek był sam”- Rdz 2,18). To pierwotne znaczenie samotności przeniknięte alternatywą śmierci i nieśmiertelności posiada też fundamentalne znaczenie dla całej teologii ciała (Jan Paweł II, Mężczyzną i niewiastą stworzyt ich. Chrystus odwołuje się do „początku” 35).
} 
na swoisty powrót do niebytu (sen ma w sobie coś z unicestwienia świadomego bytowania człowieka), do momentu przed stworzeniem, aby z niego mocą stwórczej inicjatywy Boga »człowiek « samotny mógł się wyłonić »człowiekiem« w jedności dwojga: mężczyzną i niewiastą" (Mężczyzna i niewiasta stworzyt ich. Chrystus odwotuje się do ,poczatku” 37). Jego nierozdzielność i identyczność wynika ze wspólnoty ciała, ale - jak zaznacza Ojciec Święty w Familiaris consortio - z jedności serca, jedności ducha, jedności zupełnej (nr 20)5.

12. Podobieństwo. Tym samym uzyskujemy kolejny kontekst do rozpoznania kluczowych idei papieskiej poezji. Wszak trzeba go jeszcze dopełnić o sprawę zapewne najważniejszą, którą objawia pierwszy opis stworzenia. Jan Paweł II zauważa:

Jeśli (zaś) zapożyczymy z tegoż opisu, czyli z tekstu kapłańskiego, pojęcie »obrazu Boga«, wówczas moglibyśmy wnioskować, że obrazem i podobieństwem Boga stał się człowiek nie tylko przez samo człowieczeństwo, ale także poprzez komunię osób, którą stanowią od początku mężczyzna i niewiasta. Funkcją obrazu jest odzwierciedlać tego, czyim jest obrazem - odzwierciedlać swój pierwowzór. Człowiek staje się odzwierciedleniem Boga nie tyle w akcie samotności, ile w akcie komunii. Jest wszakże „od początku” nie tylko obrazem, w którym odzwierciedla się samotność panującej nad światem Osoby, ale niezgłębiona, istotowo Boska Komunia Osób. W ten sposób opis drugi mógłby także dopomóc w trynitarnym rozumieniu „obrazu Bożego”, które to pojęcie pojawia się tylko w opisie pierwszym. (Mężczyzna i niewiasta stworzyt ich. Chrystus odwoluje się do ,początku” 37)

Człowiek jako jedność kobiety i mężczyzny jest obrazem Boga w Trójcy Jedynego, Boga niezgłębionego. Ustaliliśmy dotąd wiele, jednak te dwa bieguny porównania (Boski i ludzki) warto jeszcze rozważyć i ujawnić dalsze analogie. W Credo mówimy o Logosie, Synu Bożym: „Bóg z Boga, Światłość ze Światłości, Bóg prawdziwy z Boga prawdziwego, zrodzony a nie stworzony, współistotny Ojcu”. Takie ,zrodzenie" - świadectwo jedności, z udziałem stwórczego aktu Boga odzwierciedla opis drugi - „Teraz to jest kość z moich kości i ciało z mojego ciała” (Rdz 2,23). Mówimy o jedności „oblubieńczej” - jedno ciało, jedno serce, jedna dusza. Jedność uzyskuje swoje apogeum w miłości ofiarnej, w „zatraceniu się” w drugim. Chrystus mówi: „Nikt nie ma większej miłości od tego, kto oddaje życie za przyjaciół” (J 15,13), „zatraca się w nich” (sformułowanie bliższe istoty rzeczy niż „dla nich”). Przykład może wydać się nietrafny, dla miłości oblubieńczej niewłaściwy. Nawiązujemy jednak do niego. Pozostający w jedności mężczyzna i kobieta odzwierciedlają Miłość wszechpotężną, samą Miłość, w której relacja oblubieńcza, ofiarna i heroiczna pozostają tym samym, zrodzenie Logosu jest poświęceniem bez reszty, „zatraceniem”

\footnotetext{
${ }^{5} \mathrm{~W}$ tomie Sakrament Papież zauważa: „Miłość czyni drugie «ja» poniekąd własnym «ja». «Ja» żony staje się poprzez miłość własnym «ja» męża. Ciało jest wyrazem tego «ja», jest podstawą jego tożsamości” (35).
} 
bez reszty i zarazem pełnym odzyskaniem w poświęceniu się „Drugiego”. Takie jest „życie” w Trójcy".

13. Dar. Zjednoczenie kobiety i mężczyzny Papież rozpatruje w kategoriach daru, wzajemnego darowania. Głębię tego aktu objaśnia T. Styczeń:

Wszak tylko dlatego jestem i mogę być, że Pan we mnie jako mój Dawca jest! Jesteś z Jego daru. Jestem z Jego daru. Dając ci ciebie, jest w tobie. Dając mi mnie, jest we mnie. I musi być w tobie dając ciebie tobie, byś w ogóle istniała i była. Intimior intimo tuo! I musi być we mnie dając mi mnie, bym w ogóle zaistniał i był. [...] Drugiego możesz przyjąć w darze bez reszty tylko i wyłącznie przyjmując w nim również Mnie, jego Dawcę, owszem, przyjmując drugiego w akcie przyjęcia bez reszty przede wszystkim Mnie: jego i twego Dawcę. I tak też tylko możesz efektywnie złożyć siebie samego w darze drugiej osobie. Ze Mną, twoim i jej Pierwszym Oblubieńcem, lub wcale! („Istota więzi małżeńskiej” 137-138)

14. Nagość. Boski udział sprawia, że człowiek od-poznaje swój wysoki osobowy status w drugim, mężczyzna w kobiecie i kobieta w mężczyźnie. W tej zasadniczej dla nich relacji, „komunii osób” możemy właściwie zrozumieć znaczenie - ważnej w nauczaniu Ojca Świętego - pierwotnej nagości.

Nie odczuwali wzajemnie wstydu może w tej relacji oznaczać (in sensu obliquo) tylko taką głębię afirmacji tego, co immanentnie osobowe, w tym, co „widzialnie” kobiece i męskie, poprzez którą konstytuuje się »osobowa intymność« wzajemnej komunikacji w całej swojej radykalnej prostocie i czystości. Owej pełni „zewnętrznej” widzialności, o jakiej stanowi nagość „fizyczna” (jeśli tak można powiedzieć), odpowiada „wewnętrzna” pełnia widzenia człowieka w Bogu, to znaczy wedle miary „obrazu Boga” (por. Rdz 1,27). Wedle tej miary człowiek właśnie „jest” nagi („,byli nadzy” Rdz 2,25), zanim „poznaje, że jest nagi” (por. Rdz 3,7-10). (Mężczyzna i niewiasta stworzyt ich. Chrystus odwoluje się do ,poczatku” 49-50)

15. Dziewictwo. Odsłonięcie głębi daru przybliża nas do ostatniego zagadnienia, niezbędnego dla tworzenia kontekstu - do dziewictwa. Dziewictwo (także bezżeństwo) wynika z tych samych założeń metafizycznej antropologii wywiedzionej z Biblii i tłumaczy się jednością mężczyzny i kobiety. „Dziewictwo i celibat dla Królestwa Bożego nie tylko nie stoją w sprzeczności z godnością małżeńską, ale ją zakładają i potwierdzają” (,Familiaris consortio”. Tekst 22). Zarówno jedno, jak i drugie, w formie im właściwej, są konkretnym wypełnieniem najgłębszej prawdy

\footnotetext{
${ }^{6}$ Efektem tego jest jedność Boga w Trójcy Jedynego. Gdyby oddanie nie było ostateczne, nie było „bez reszty”, zamiast jedyności, Bóg byłby jakimś tworem politeistycznym. Wielu teologów podkreśla, że Bóg jako Trójca Święta jest „rodziną”, oczywiście te relacje - zgodnie z zastrzeżeniem Mulieris dignitatem - są ponadcielesne, ponadludzkie, całkowicie Boskie, „całkowicie inne”. W tym sensie Boga jako Rodzinę ujmuje Jacek Bolewski. Prawda o Trójcy została zawarta w Nowym Testamencie, „gdzie - jak zauważa autor - obok osoby Ojca i Syna, pojawiła się trzecia, wyrażająca właśnie żeński wymiar bóstwa. Nazywamy Ją tradycyjnie Duchem Świętym, ale dla wyrażenia dopełnienia wobec Ojca-Syna lepsza byłaby formuła: świętość Duchowa, a najlepsza - Matka” (Bolewski 230).
} 
o człowieku, o jego istnieniu „na obraz Boży”. Małżeństwo obejmuje całą widzialność w świecie, cielesność, męskosśc/kobiecość, nagość i pierwotną niewinność - te atrybuty zostają zachowane w dziewictwie, którego podstawą są ontyczne (bytowe) warunki stworzenia człowieka mężczyzną i kobietą. Jednakże ten powszechny warunek jest w dziewictwie osiągany na wyższym poziomie bytowej organizacji człowieka, w wymiarze odkupienia, w którym duchowo owocuje również zjednoczenie mężczyzny i kobiety. $\mathrm{W}$ istocie dziewictwo na tym poziomie i w tym zwrocie ku Bogu spotyka się z małżeństwem (z „sakramentem stworzenia”). „Duchowy efekt, duchowy „substrat” małżeństwa i dziewictwa już się istotnie nie różnią, sprowadzają się do tego samego. Mowa o duchowej płodności, z odkupienia (jako nowego stworzenia), mowa o nasieniu słowa od Boga (Mężczyzna i niewiasta stworzyt ich. Sakrament 53). Małżeństwo, jak i dziewictwo stają się zaczątkiem pozadoczesnej przyszłości (Mężczyzna i niewiasta stworzyt ich. Sakrament 65). Bezżenność odwraca te relacje: najpierw sens odkupieńczy, dalej oblubieńczy (i tu: nawiązanie do postaw Chrystusa).

16. Teologia ciała w poezji i nauczaniu. Opracowanie nauczania Jana Pawła II wyodrębnione w tej części pozwoliło uniknąć przywoływania całego aparatu myślowego w toku czynności interpretacyjnych i poprzestać na prostych odwołaniach do treści nauczania. Omówione w części 2. poetyckie teksty o tematyce kobiecej znajdują odniesienie do myśli Karola Wojtyły po wyborze na Stolicę Piotrową. Jak wiadomo, powstały one wiele lat wcześniej z wyjątkiem Tryptyku rzymskiego napisanego pod koniec pontyfikatu. Trudno tu jednak o anachronizm. Myśl Karola Wojtyły dojrzewała równolegle do nich i znalazła wyraz w katechezach i innych dokumentach pierwszych lat pontyfikatu. Stąd zbieżność i jednorodność myśli i poezji, o czym była mowa na początku obecnego opracowania. Nakreślenie kontekstu teologii ciała i teologii kobiety, chociaż maksymalnie zredukowane, może, w tak niewielkim artykule, przytłaczać wielością danych. Jednak było to konieczne zarówno dla uniknięcia niedopowiedzeń, jak i z potrzeby pełnego oglądu przesłania papieskiej poezji. Pozwoliło to część drugą opracowania ograniczyć do samych analiz wierszy-medytacji Jana Pawła II. Uważam, że dokonane w nich ustalenia są dostatecznie czytelne w kontekście jego myśli, scharakteryzowanej w części pierwszej. Toteż odrębne podsumowanie wyników analiz nie jest konieczne. 
II

\section{ANALIZY POETYCKICH MEDYTACJI O KOBIECIE}

\section{Profile Cyrenejczyka}

5. Dziewczyna zawiedziona w miłości (Wojtyła, Ukryty blask 88-89)

Ramę tekstu wyznacza komentator, liryczny nauczyciel, zwrócony ku sytuacji duchowej dziewczyny, która utraciła kontakt z bliską osobą. Mowa o cierpieniu, które rodzi się z braku bliskości, jest uczuciem bolesnym, przeżywanym w samotności. Dziewczyna powtarza niejako samotność pierwszego człowieka (ādāma), który nie znalazł jednoczącej relacji z bliską mu istotą. Jej kondycja „cofnęła się” niejako do tego pierwszego bytowego stanu, do doznania pierwotnej samotności. Jednak sytuację dziewczyny tłumaczy „drugie” stworzenie człowieka, i „druga” samotność, zaistniała po rozpadzie wzajemnej jedności. W horyzoncie tej sytuacji nie jest już tylko Bóg Stwórca, ale Zbawca, przychodzący do człowieka po utracie rajskiej niewinności. Dlatego gdy liryczny nauczyciel konstatuje jej samotność: „lecz ty zanadto jesteś osią swoich spraw" - wskazuje na konieczność przezwyciężenia tej „drugiej” samotności; dziewczyna słyszy: „osią tych spraw nie jesteś”. Niezależnie bowiem od odrzucenia jej daru przez bliską osobę, utrata nie obejmuje wszystkiego, nie obejmuje zbawczego zaangażowania Boga. Właśnie w doświadczeniu bólu, po odrzuceniu daru serca samotność musi ustąpić intymnej Obecności. Trzeba tylko to sobie uświadomić - sugeruje medytujący nauczyciel: „a Ten, co nią jest [osią spraw dziewczyny] / też nie znajduje miłości - / - gdybyś zdołała to pojąć” (88). O obecności Boga w jestestwie człowieka (mężczyzn i kobiet) mówi w cytowanym wyżej komentarzu do nauczania Jana Pawła II T. Styczeń. Jego wykładnię można odnieść do dziewczyny i jej byłego partnera, przypomnijmy końcową część tej wypowiedzi: „możesz efektywnie złożyć siebie samego w darze drugiej osobie. Ze Mną, twoim i jej Pierwszym Oblubieńcem, lub wcale!” (Styczeń, „Istota więzi małżeńskiej” 138). Mowa o integralnym, ostatecznym ukochaniu kobiety i mężczyzny przez Boga, o osobliwościach relacji „sakramentu stworzenia” i zarazem sakramentu małżeństwa, jako zbawienia, i o Tym, który „też nie znajduje miłości”. Odrzucenie zatem daru osoby - jak chce nam powiedzieć podmiot papieski - dotyka również Boga-Oblubieńca, jest źródłem jego cierpienia, zawodu i odrzucenia, jego współistnienia w spełnionym przez dziewczynę darze miłości.

\footnotetext{
${ }^{7} \mathrm{~W}$ opracowaniu wierszy korzystamy z wydania: Karol Wojtyła. Ukryty blask. Wydanie i posłowie Jan Sochoń, Wydawnictwo Uniwersytetu Kardynała Stefana Wyszyńskiego, 2003, natomiast wyjątkowo z wydania: Karol Wojtyła. Poezje i dramaty. Wybór i układ Marek Skwarnicki i Jerzy Turowicz. Wyd. 3, Znak, 2001.
} 
W dalszej części utworu położenie dziewczyny jest widziane z perspektywy losów rodzaju ludzkiego, historii upadku człowieka. Ta perspektywa została rozwinięta w wersach 10-15, gdzie ze wzmożoną intesywnością wyłania się wizja raju, ciemna, księżycowa, pełna świeżości, pulsująca metaforycznie wyrażonym napięciem, naznaczona niepokojem ludzkiego serca, zstępującym do środka świata. „Pień drzewa i ziemia w księżycu: niedoszeptany tli trójkąt./ Mgły nie dźwignęły się jeszcze. Serca dzieci wyrastają nad rzekę./ Czy zawsze tak będzie - pytam - gdy wstaną stąd i pójdą?” (89). Podmiot, mówiąc o „zawiedzionej” dziewczynie, odwołuje się znów do biblijnego archetypu jednego ciała, „ciała z mojego ciała”, utraty pierwotnej nagości, pojawienia się wstydu, który jest związany z zagrożeniem bytu. Odejście osoby i porzucenie jedności staje się groźne, gdyż jest także utratą ,ja” ofiarowanego drugiemu. W tej rajskiej perspektywie trzeba postrzegać wartość jedności utraconej. Odejście z Raju jest również ryzykiem „,rozejścia się” i utraty jedności, danej pierwotnie w „sakramencie stworzenia”. „Tego, co w was się zaczęło - mówi podmiot papieski - czy potraficie nie popsuć,/ czy będziecie zawsze oddzielać dobro i zło?” (89). Zniweczona harmonia Raju jest trwałą sytuacją człowieka, w której górują reminiscencje, kłamstwa, zdrady, nieposłuszeństwa i przerażające skutki owoców wiedzy o dobru i złu.

\section{Magdalena (Wojtyła, Ukryty blask 91)}

Magdalena doznaje w sobie rozdwojenia. Duchowe przebudzenie, próba przełamania władzy ciała, znajduje wythumaczenie w biblijnym rozpoznaniu walki duchowej i konfliktu w człowieku: ,duch wprawdzie ochoczy, ale ciało słabe” (Rz 7,14-25, zob. też Mt 26,41). To zasadniczy temat rozwoju sytuacji lirycznej. Magdalena mówi: „Duch się «przesunął nagle» a ciało jeszcze zostało/ na dawnym swoim miejscu. Dlatego ogarnął mnie ból” (91). Nie jest to jednak stałe obciążenie, o jakim mówi św. Paweł, jakaś conditio humana. To początek wzrastania, bolesne przywracanie stanu Raju, trudna droga ku jedności w człowieku, gdzie ciało, aby zażegnać wewnątrzny konflikt, winno karmić się duchem, przywrócić gotowość jedności. Toteż droga Magdaleny nie prowadzi do poszukiwania bliskości w horyzoncie równie zagubionych ludzi. Wybiera własne wzrastanie, wyjście z błędnych relacji, przeobrażenie siebie, zrodzenie w sobie „nowego człowieka” w bólu i ofierze ponoszonej dla Boga-Człowieka. „Miłość boli: - mówi o tym wzrastaniu - tygodnie, miesiące, lata./ Język i podniebienie jak korzeń suchego drzewa,/ wargi odarte ze szminki. Prawda długo gruntuje błąd" (91). Są tu metonimie - dla oznaczenie suchości, jako braku życia, ale też celowo podejmowanej ofiary. Woda jest z kolei wielorakim symbolem życia. Ta opozycja: suchość - woda należy do stałych elementów poetyckiej 
wyobraźni Jana Pawła II ${ }^{8}$. Ów brak życia, wysychanie z niedorastania do miłości Bożej ma też konotacje kobiece - miłości, która nie może się spełnić, duchowej, ale wyrażanej przez znaczenia cielesne: ust, języka, podniebienia czy suchości warg, pozbawionych szminki. Odsłanianie własnych błędów wobec Boga-Człowieka, który w Magdalenie jest wewnętrzną Obecnością. Obarczanie Boga „suchością”, niedostatkiem miłości łączy się z poczuciem braku możliwości zadośćuczynienia za ofiarę, jaką powszechnie ponosi. „Jednak suszę całego świata/ - oświadcza Magdalena - nie ja odczuwam, lecz On" (91).

Pieśń o blasku wody (Wojtyła, Ukryty blask 46-60)

Już u początku, w liryku Nad studnia w Sychem, obraz studni uzmysławia głębię Boga, metaforyczne ekwiwalencje między wodą życia, światłem i słowem ukazują miejsce ludzi w przestrzeni Boga. „Przecież w Tobie drży tylu ludzi/ prześwietlonych blaskiem Twoich słów - / jak źrenice prześwietla blask wody... // Tych ludzi znużeniem zarazem i światłem znasz" (48).

W kolejnym wierszu 2. Gdy otworzysz oczy w gtębi fali... (49-50) powtarza się motyw Bożej obecności w ludziach, ,odsłania ich to, co najbardziej ukryte w nich/ i czego żaden nie wypala płomień"; cytat wyjątkowo z książki: Poezje i dramaty (36). Podmiot autorski mówi: „Nie, nie - to nie jesteście wy tylko - a jeśli nawet wy, /tedy obecność wasza nie tylko trwa, lecz objawia - / Byle oczy otworzyć inaczej,/ otworzyć inaczej niż zwykłe/ I nie zapomnieć widzenia, którym wówczas wzrok się napawał" (50).

W medytacji 3. Stowa niewiasty u studni, które wypowiedziała odchodzac (51). Bóg przychodzi do kobiety, która zna dobro i zło, otwarta na wiedzę (wedle formuły: „Teraz otworzyły się obojgu oczy i poznali, że są nadzy” (Rdz 3,7). Poznanie nagości łączy się przede wszystkim z odczytaniem własnej pozycji względem innych. Pojawia się wraz ze świadomością, że inni mogą zawłaszczyć najbardziej osobistą sferę człowieka, zaś natychmiastową reakcją na to jest wstyd. Wstyd chroni obarczone grzechem ,ja" przed nadużyciami innych. Jest totalnym ukryciem następstw grzechu powszechnego (pierworodnego), z którego bierze się cała ułomność człowieka, również grzechy indywidualne. Samarytanka unikając innych, przyszła do studni w południe, jak wiadomo, z powodu wstydu. Z kolei pojawiający się przy studni Jezus przekracza to osobowe zabezpieczenie, nie respektuje zasady wstydu, sięga do spraw intymnych i skrzętnie ukrywanych. To samo czyni w wierszu. Kobieta mówi:

\footnotetext{
${ }^{8}$ Wprawdzie większość tekstów powstała wcześniej i winna być sygnowana nazwiskiem Karola Wojtyły, stosujemy i do nich autorską nazwę „Jan Paweł II”.Teksty wcześniejsze, również te filozoficzne stają się integralną częścią przesłania w trakcie pontyfikatu, a teksty literackie uzyskały jego legitymizację w tym okresie.
} 
„i milcząc tylu ludzi przeprowadziłeś przeze mnie/ i dróg dalekich - i ulic rosnące w ludziach zarzewie" (51). Wchodząc w ludzki wstyd", inną drogą przywraca sytuację, która była na początku, poza niewiedzą, gdyż zasada rozróżniania dobra i zła, zasada separacji godzi w zdolność widzenia spraw najważniejszych, całkowitego otwarcia, widzenia Boga twarzą w twarz. W wyniku spotkania przy studni, kobiecie w wierszu Wojtyły przywrócone zostaje widzenie Boga. W wielkim trudzie następuje powrót ku sytuacji Raju, właśnie sytuacji przekraczającej (i poprzedzającej) wstyd.

W medytacji 4. Późniejsze rozpamiętywanie spotkania kobieta mówi: „Widział mnie w sobie. Posiadał mnie w sobie./ Przenikał we mnie bez trudu/ i wstydem wytryskał we mnie i myślą tłumioną od dawna./ Jakby dotykał rytmu w moich skroniach i znużenie ogromne dźwigał we mnie nagle... / i pieczołowicie..." (52). Kobieta przemierza w Bogu drogę odwrotną. Odsłania rzeczy tłumione, porzuca wstyd, który tworzył bariery dla innych, jest naga przed Bogiem, który przejmuje na siebie ciężar jej życia. I tu znów, jak w innych wierszach tego poematu pojawiają się reminiscencje Raju: „Słowa były proste. Szły koło mnie jak owce wabione,/ A wewnątrz ... zrywały się we mnie ptaki, drzemiące w gniazdach" (52-53). Ten wiersz - efekt „późniejszego rozpamiętywania” podąża jeszcze dalej. Kobieta mówi: „Był cały w moim grzechu i w mej tajemnicy./ Powiedz, to musiało boleć - to musiało ciążyć/ (fala myśli opada tak jak wieko z metalu)" (53).

W medytacji 7. Rozważania ponowne dodaje jeszcze: „Ten ciężar, który ze mnie wyjąłeś - ja rozpoznam dopiero powoli/ miarą własnego znużenia wśród tylu walk [...] Przecież wiem, że nie zawisło w próżni/ to brzemię, które ze mnie wyjąłeś którego żadna z wag nie odważy - nie odróżni” (58).

Wracamy do medytacji 4. W Późniejszym rozpamiętywaniu spotkania kobieta zwraca się do Boskiego Oblubieńca z zamiarem zdjęcia z niego własnego ciężaru, „wtedy nie docierpiałam w Tobie właściwych rozmiarów - oświadcza/ Powiedz... dziś miłość chciałaby sobie przywrócić ten ból.../ odebrać go Tobie i w siebie jak taśmę ostrą przewinąć...// Za późno, dziś każdy ból, który powraca od Ciebie,/ po drodze odmienia się w miłość" (53). Niemożliwa jest zwykła wzajemność, przejęcie ciężaru krzyża, dorastania do Boga, ulżenia Bogu, gdyż wszelki ból, który mógłby powrócić od Boga, zamienia się wyłącznie w miłość, bólu już nie ma. Zbawienie od Boga (zgodnie z przesłaniem Dives in misericordia) jest nowym stworzeniem, gdyż dawne rzeczy przeminęły ${ }^{10}$. Mówimy o tym w kontekście nauki o początku. W relacji kobiety do Boga-Oblubieńca można rozpoznać biblijny paradygmat ducho-

${ }^{9}$ Jezus dokonuje absorpcji wstydu przez miłość. Źródłem absorpcji jest miłość seksualna, ale też miłość stwórcza, która jest podstawą bytu człowieka. Bóg zna człowieka, w każdej sytuacji, w każdej sytuacji człowiek jest nagi przed Bogiem. Zob. Półtawska, 207-208.

${ }^{10}$ Zob. Jan Paweł II, Dives in misericordia 26. 
wej jedności kobiety i mężczyzny, jest on jednak przekroczony w stronę pierwotnej i głębszej jeszcze jedności.

W medytacji 6. Samarytanka o tej innej jedności kobieta mówi: „Owa studnia złączyła mnie z Tobą,/ owa studnia wprowadziła mnie w Ciebie. [...] ona mnie w oczy twoje przeniosła i w nich zamknęła" (56).

Inaczej wygląda to w utworze 5: Rozmowy, które prowadzit w niej On i ludzie ze ściany wieczoru. W kobiecie spotyka się Bóg z mnóstwem ludzi. Bóg zapewnia, że ludzie mają w sobie samych jego profil, jako nieusuwalną podstawę prawdy w nich samych. Jednak w przeciwieństwie do kobiety, ludzie nie deklarują miłości zadośćuczynienia ani współodkupienia, por. kategorie mistyki współczesnej (Plus). Stąd wypowiedziane w kobiecie słowa Boga: ,dlaczego ze mnie swojego nie wyjmujecie krzyża/ jak ja wyjąłem z was?/ gdy płonął w waszych ramionach i zwisał w ciężkim tchu" (55).

Odkupienie szuka Twego kształtu by wejść w niepokój wszystkich ludzi (Ukryty blask 124-140)

I. Weronika. W wierszu Weronika mowa o wyjściu z codzienności poprzez myśl, która sięga istoty człowieka i ogarnia świat. Myśl w intencji Papieża daleko wykracza poza znaczenia, które są jedynie poznawczą treścią. Myśl kształtuje natomiast realną aktywność osób. „Przez myśl świat nie uchodzi w krainę samych znaczeń/ nie uchodzą zwierzęta, ni ludzie, kwiaty w wazonach/ czy też kwiaty na łąkach ludzkiego osamotnienia/ ani krople krwi na czole umęczonego człowieka -" (127). Myśl odnosi się do niedocieczonej miłości Boga, który uczestniczy w życiu codziennym. Mówi do Weroniki: „Tutaj czekam na twoje dłonie pełne codziennych poczynań/ tutaj czekam na twoje dłonie trzymające zwyczajne płótno" (128). W codzienności kobieta przekracza siebie: „wnieś twe ręce Weroniko,/ wnieś twe ręce/ i dotknij twarzy człowieka" (128). Poetycki podmiot podkreśla wagę codzienności, zwyczajnego życia. Tylko w codzienności, a nie w nie-codziennych uczynkach Weronika znajduje własne spełnienie, spotyka miłość niedocieczoną. Mowa w wierszu o realizmie spotkania z Bogiem samym w codziennym życiu.

III. Imię. Serce Weroniki zgodnie z imieniem staje się obrazem - prawdy, imię wedle księgi początku objawia istotę człowieka. Weronika dąży do widzenia Boga, idącego ku miejscu Skazania. Pragnie widzeć, mieć prawdziwy obraz Boga w sercu, aby czuć i trwać w miłości. Nie chodzi tylko o współczucie, pragnienie ujrzenia Oblubieńca, ale - jak podpowiada filozoficzny kontekst - o Dawcę daru, w którym człowiek jest darowany sam sobie. Weronika przedziera się z miłością do źródła własnego istnienia. W medytacji czytamy: ,chcę być blisko, tak bardzo blisko, / by żadna pustka nie objawiła mi siebie/ w oderwaniu od Ciebie,/ by nieobecność Twoja nie wracała do mnie/ jak zaprzeczenie mnie samej/ - dlatego biegnę: przedziera się 
serce/ przez mrok, jaki wytwarza bliskość" (135). Ten akt miłości, ofiarowanie chusty służy także innym na tej drodze. Dla Weroniki Bóg jest dawcą zarówno istnienia, jak i nieprzemijającej tożsamości osobowej. Związek z Boskim Oblubieńcem jest równie głęboki, jak u Samarytanki, która wraca do Boga za sprawą jego miłości odkupieńczej.

IV. Odkupienie. O odkupieniu mowa w ostatnim fragmencie medytacji, poświęconej Weronice. Chusta jest znakiem obecności Jezusa, swoistym sakramentem. W istocie świadczy o wszelkich postaciach ,sakramentu stworzenia”, o którym mowa w pierwszym tomie konferencji wygłoszonych w czasie środowych audiencji ( $M e ̨ z$ czyzna i niewiasta stworzyt ich. Chrystus odwotuje się do „poczatku”). Weronika, trzymając chustę, postrzega siebie podobnie, jak w chwili dramatycznego dążenia do bliskości z przechodzącym Jezusem. „W tym płótnie jest znak bliskości, w którym się chronisz przed swoim własnym kształtem./ Przed takim kształtem życia, z którym nie można się zgodzić./ Przed takim Pęknięciem, w którym oddala się to, co najbardziej jest wewnątrz" (Ukryty blask 137). Chusta jest sakramentem Jezusa, warunkiem zapewnienia i uratowania istnienia kobiety, jednak oprócz tego, że jest „sakramentem stworzenia”, jest też sakramentem nieustannej obecności, usuwa tęsknotę - głód bliskości. Weronika mówi: „odszedłeś, a idziesz przeze mnie wciąż, wydobywasz dalekim spojrzeniem odbitego/ na płótnie Oblicza taki pokój, którego/ wciąż szuka mój niespokojny kształt./ Pokój: jedności istnienia" (139). Jan Paweł II tę ontologiczną obecność w kobiecie traktuje jako Odkupienie. „ODKUPIENIE jest nieustanną bliskością TEGO, KTÓRY ODSZEDŁ” (138). Poeta wskazuje ostateczne konsekwencje tego odkupienia, przemianę Weroniki, jej przebóstwienie. Widać to w ostatnich wersach medytacji: „Stworzenia pytać będą o życiodajne źródło, które bije z twojej postaci/ Weroniko, siostro -" (140); ponadto wskazuje też jej misję: „Odkupienie szukało twego kształtu, by wejść w niepokój wszystkich ludzi” (140).

\section{Tryptyk rzymski, cz. I i II (7-23)}

Sięgamy teraz po Tryptyk rzymski - utwór, który powstał wiele lat później od omówionych tu poezji oraz po najważniejszych tekstach nauczania, wygłoszonych w pierwszych latach pontyfikatu. Papież nawiązuje w nim do wyraźnie zaznaczonego odróżnienia etapów stworzenia człowieka: ādāma od następującego po tym stworzeniu człowieka jako mężczyzny i kobiety. Te dwa etapy, dwie konstytucje bytowe są ukazane jako przejście od człowieka samotnego do człowieka zespolonego w sobie, w jedności kobiety i mężczyzny. Papież - co zrozumiałe - nie podejmuje w medytacji owych dyskursywnych pogłębien, zawartych w tekstach konferencji w czasie środowych audiencji, jednak wykonuje zabieg radykalny, być może bardziej jeszcze istotny dla podkreślenia odmienności tych dwu stanów ontologicznych. Człowieka $\bar{a}$ āma umieszcza odrębnie - w pierwszej części Tryptyku, stworzenie mężczyzny 
i kobiety rozważa natomiast w części drugiej. Samo rozróżnienie wzmacnia papieską koncepcję antropologii (fundamentalnej). W efekcie pełniej ukazuje jedność kobiety i mężczyzny, znacznie wyraźniej kreśli też stan odmienności i jedności płci. Zarazem jednak wykracza poza rozpoznany hermeneutycznie sens Księgi Genesis. Stanu ādāma (człowieka w ogóle) nie ogranicza w medytacji do genezyjskiej, archaicznej przeszłości ludzkiego rodzaju. Samotność w jej biblijnym sensie zostaje pokonana wraz ze stworzeniem człowieka mężczyzną i kobietą. Pozostaje jednak inny typ samotności, który stanowi trwały element kondycji ludzkiej. Ku tym wymiarom samotności uniwersalnej i nieusuwalnej zmierza medytacja Jana Pawła II w pierwszej części Tryptyku. Tu myślenie o człowieku, także o człowieku współczesnym, w przywołaniu przez Autora doświadczeń wieku dwudziestego, wskazuje ciągłość, nić zgodności z historią biblijną, świadczy o tym m.in. nazwanie człowieka współczesnego w pewnych okolicznościach życia również imieniem ādām. Jest to wyrazem powszechnej ludzkiej kondycji, zarówno w jej perspektywie biblijnej, jak i w perspektywie naszego czasu. Paradygmat człowieka samotnego rysuje się już w księdze początku, gdy człowiek nie znajduje właściwego dla siebie otoczenia i istot odpowiednich dla swoich duchowych potrzeb. Co prawda samotność traci wagę, gdy człowiek w kolejnym etapie stworzenia znajduje w sobie stan wzajemnego odniesienia i jedności w kobiecie i mężczyźnie. Jednak ta wzajemność, skupienie na sobie w miłości nie zmienia sytuacji człowieka wobec reszty świata i całego stworzenia, które niezmiennie człowieka otacza ${ }^{11}$. Anonimowe, obce i „nieludzkie” otoczenie przejawia się w świecie biblijnym, choć po stworzeniu pierwszej pary nie jest już wprost konfrontowane z człowiekiem. Podobnie jest w świecie współczesnym relacje personalne czy miłość oblubieńcza są wprawdzie możliwe, wszelako nie usuwają niepokoju i zagubienia człowieka w kosmosie. Zasadne okazuje się więc odwołanie do biblijnego paradygmatu samotnego Adama, który pozwala również zrozumieć egzystencję człowieka dzisiejszego, adresata słów Jana Pawła II.

W medytacji części pierwszej ukazany został właśnie człowiek samotny. Nic nie odpowiada na jego pojmowanie świata, nie znajduje też wzajemności w świecie, który chociaż wywiedziony z Przedwiecznego Słowa, milczy, podobnie jak Bóg, który swoje świadectwo powierzył w depozyt światu. Jest to samotność mowy, intencji, pojmowania i zdumienia. Samotność związana jest przede wszystkim ze

\footnotetext{
${ }^{11}$ Obydwa stany mogą wspomagać samorozumienie człowieka, który w okolicznościach życia znajdować się może w stanie samotności i zdumienia światem bądź w stanie jedności i innego widzenia świata właśnie poprzez drugiego człowieka.
} 
zdumieniem. Zdumienie to podstawowa dyspozycja ludzkiego bytu, poznawcza, decydująca o statusie człowieka, o jego człowieczeństwie ${ }^{12}$.

Człowiek doznaje zdumienia światem, który świadczy o Bogu, choć zarazem nie jest w stanie Go wyrazić. Celem zatem nie jest epifania Boga, ale oczekiwana od świata pomoc w Jego rozumieniu. Pomocy tej człowiek nie uzyskuje i tu dopiero pojawia się poczucie sięgającej najgłębiej w sferę ludzkiego bytu samotności, samotności poznawczej, swoiście „ontologicznej”.

W części 1: Zdumienie, zarówno osamotnienie, jak i zdumienie człowieka trzeba widzieć w skali całej rzeczywistości, a zstępowanie coraz niżej w zarysowanym w medytacji górskim krajobrazie rozumieć jako oddalanie od źródła. Podmiot śledzi nieustannie analogie życia własnego i przyrody, śledzi przede wszystkim różnicę. Świat wkracza w człowieka i go zdumiewa swoją odmiennością, zdumiewa brakiem zdumienia, odmiennością ,ja” od świata pozbawionego zdumień. Jest w medytacji również biblijna reminiscencja ādāma jako pana wszelkiego stworzenia. Świadczy o tym wezwanie wobec elementów kosmosu: „,Zatrzymaj się! - masz we mnie przystań «/ »we mnie jest miejsce spotkania/ z Przedwiecznym Słowem « - / »zatrzymaj się, to przemijanie ma sens « / »ma sens... ma sens... ma sens!«” (10). Przyroda nie odpowiada, a zatem jedynie osamotniony w swym zdumieniu człowiek przedziera się do źródła. Jan Paweł II ukazuje ramy egzystencji i powołania człowieka między dwoma progami. Przekroczenie pierwszego rodzi ludzkie zdumienie anonimowym kosmosem, próg drugi (w 2 części Tryptyku) jest Słowem niewidzialnym, odwiecznym, boskim, w którym wszystko się stało, progiem, ,za którym żyjemy, poruszamy się i jesteśmy", za którym rozpoczynają się dzieje człowieka (por. 16).

Tematem drugiej części Tryptyku, medytacji dotyczącej przedstawień w Kaplicy Sykstyńskiej, jest rzeczywistość między Początkiem, wyłonionym z niebytu, a Kresem. Zwracamy uwagę na wymowę początku - stworzenie pierwszych ludzi w części: Obraz i podobieństwo. Papież nawiązuje do pierwszego opisu stworzenia z Księgi Rodzaju: „Uczynił Bóg człowieka na swój obraz i podobieństwo. / Mężczyzną i niewiastą stworzył ich - / i widział Bóg, że było bardzo dobre,/ oboje zaś byli nadzy i nie doznawali wstydu" (18). W przywołanym fragmencie pojawiają się kategorie dokładnie analizowane w konferencjach z katechez. Mowa o dobru stworzenia, na-

${ }^{12}$ Doznaniu samotności Papież poświęcił - jak wiadomo - osobną część swych katechez. W jego nauczaniu samotność jest ontologicznym brakiem oblubieńczej relacji, oblubieńczej obecności u pierwszego człowieka. Toteż jej przezwyciężenie wiąże się z tajemnicą ponownego stworzenia człowieka jako mężczyzny i kobiety, pozostających we wzajemnej jedności. O ile w pierwszym rozumieniu obrazem Boga w człowieku jest (mówiąc zgodnie z Papieżem) jego człowieczeństwo, gdyż nie posiada on w sobie relacji międzyosobowej. W drugim rozumieniu człowiek charakteryzuje się wewnętrzną bytową relacją, tym samym odzwierciedla Boga w jego stanie trynitarnym. Na obydwa typy podobieństwa do Boga Jan Paweł II zwracał uwagę w pierwszym tomie konferencji. 
gości i braku wstydu oraz znaczeniu daru. Papież podkreśla zanurzenie wszystkiego w obecności Bożej, w Bożym widzeniu, gdzie: „wszystko odkryte i odsłonięte jest przed jego oczami”; „Nagie i przejrzyste -/ Prawdziwe, dobre i piękne -” (15); „Czyż nie On właśnie widzi wszystko w całej prawdzie?” (20). Boże widzenie, które kreuje doskonałość kobiety i mężczyzny, poprzedza ich widzenie wzajemne. To jakby drugi wymiar obrazu i podobieństwa. Dzięki temu oni też „widzą siebie w całej prawdzie:/ byli oboje nadzy... / Oni także stali się uczestnikami tego widzenia, / które przeniósł na nich Stwórca./ Czyż nie chcą nimi pozostać?/ Czyż nie chcą odzyskiwać tego widzenia na nowo?/ Czyż nie chcą dla siebie być prawdziwi i przejrzyści -/ jak są dla Niego?" (20).

Jan Paweł II skupia uwagę na wskazanym wcześniej momencie widzenia. Podkreśla związek stwarzania osób na obraz i podobieństwo ze zdolnością widzenia, jaka staje się ich udziałem jako imago Dei, dzięki czemu pogłębiają swoją wzajemną współobecność. Są wobec siebie nadzy nie tyle nagością pierwotnej niewinności i bezgrzeszności, jaką pierwsza para uzyskuje na początku, ale w wyniku przejęcia widzenia, które posiada Bóg i które dzięki obrazowi i podobieństwu jest również im udzielane. Kobieta i mężczyzna są wobec siebie nadzy nagością, którą Bóg widzi każde z nich. Stąd apel podmiotu medytacji o partycypację w widzeniu Boga, w prawdzie i przejrzystości jego spojrzenia. Widzenie takie jest wartością, do której nawołuje Papież, warto je zachować, warto też je odzyskać dla doskonałości miłości oblubieńczej, gdzie Bóg „pozwala im uczestniczyć w pięknie, jakie w nich tchnął!!/ To On otwiera im oczy" (21).

Papież wraca też do myśli zawartej w katechezach na temat trynitarnego pojmowania Boga jako Komunii Osób, której odzwierciedleniem jest jedność kobiety i mężczyzny. Polega na wzajemnym darowaniu; ,wzięli w siebie - na ludzką miarę - to wzajemne obdarowanie,/ które jest w Nim./ oboje nadzy.../ [...] trwa uniesienie. Żyją świadomi daru, choć może nawet nie umieją tego nazwać./ Ale tym żyją. Są czyści” (22). Stają się prasakramentem - czyli widzialnym znakiem odwiecznej Miłości. Człowiek, którego nie można pojąć bez oblubieńczego daru wobec drugiego, odzwierciedla Trójcę Świętą ${ }^{13}$. Sprawa kobiety w odczytaniu medytacji zawartych w Tryptyku jest rozważana przede wszystkim w relacji do osoby mężczyzny, czyli w zgodzie z papieską teologią ciała i teologią kobiety.

\footnotetext{
${ }^{13}$ Komunia Osób Bożych jest nie tylko wzajemnym darem, ale - jak zaznaczam w części I - jest wzajemną ofiarą. Ta idea została w pewnym stopniu przybliżona w studium Miłość i odpowiedzialność. Na odpowiednie fragmenty zwrócił uwagę Grzegorz Hołub. Cytujemy za nim: „»Istotą miłości oblubieńczej jest oddanie siebie, swojego 'ja' "«" (88). Albo w innym miejscu powie on jeszcze dobitniej: „najpełniejsza, a zarazem jakby najradykalniejsza forma miłości leży też w tym, aby właśnie siebie dać, aby to swoje nieprzekazywalne i niedostępne ‘ja' uczynić czyjąś własnością” (89). Źródło cytowań (Hołub 403).
} 


\section{BIBLIOGRAFIA}

\section{PODMIOTOWA}

Jan Paweł II. „Familiaris consortio”. Tekst i komentarze, Jan Paweł II naucza, t. 8, red. Tadeusz Styczeń, Redakcja Wydawnictw Katolickiego Uniwersytetu Lubelskiego, 1987.

Jan Paweł II. Dives in misericordia. Tekst i komentarze, red. Stanisław Nagy, Redakcja Wydawnictw KUL, 1983.

Jan Paweł II. List apostolski „, Mulieris dignitatem”. O godności i powołaniu kobiety. Pallottinum, 1988.

Jan Paweł II. Mężczyzna i niewiasta stworzyt ich. Chrystus odwoluje się do „,początku”. O Jana Pawta II teologii ciała, Jan Paweł II naucza, t. 1, red. Tadeusz Styczeń, Redakcja Wydawnictw KUL, 1981.

Jan Paweł II. Mężczyzna i niewiasta stworzyt ich. Sakrament. O Jana Pawła II teologii ciała, Jan Paweł II naucza, t. 4, red. Tadeusz Styczeń, Redakcja Wydawnictw KUL, 1998.

Jan Paweł II. Tryptyk rzymski. Medytacje. Wydawnictwo św. Stanisława BM, 2003.

Wojtyła, Karol. Poezje i dramaty. Wybór i układ Marek Skwarnicki i Jerzy Turowicz. Wyd. 3, Znak, 2001.

Wojtyła, Karol. Ukryty blask. Wydanie i posłowie Jan Sochoń, Wydawnictwo Uniwersytetu Kardynała Stefana Wyszyńskiego, 2003.

Wojtyła, Karol. Miłość i odpowiedzialność. Wyd. IV, Towarzystwo Naukowe Katolickiego Uniwersytetu Lubelskiego, 1986.

\section{PRZEDMIOTOWA}

Adamiak, Elżbieta. „Nowy wiek i feminizm”. Kobieta w nowym wieku, red. Jacek Bolewski, Wydawnictwo WAM, 2001.

Bolewski, Jacek. Biała bogini, czarna madonna. Maryjne światło w ezoterycznym odcieniu. Wydawnictwo „Rhetos”, 2005.

Chudy, Wojciech. „Oblicza personalizmu i ich konsekwencje”. Kwartalnik Filozoficzny, t. XXVI, z. 3, 1998.

Hołub, Grzegorz. „Kobiecość i męskość w spełnieniu osoby w ujęciu Karola Wojtyły”. Wokół antropologii Karola Wojtyty, red. Andrzej Maryniarczyk, Paulina Sulenta i Tomasz Duma, Polskie Towarzystwo Tomasza z Akwinu. Katedra Metafizyki KUL, 2016, ss. 395-406.

Pismo Święte Starego i Nowego Testamentu, t. 1-3, Ksiegarnia św. Wojciecha, 1973-1975 [tzw. Biblia Poznańska].

Plus Raoul J. Szaleństwo krzyża. Wydawnictwo Księży Jezuitów, 1947.

Półtawska, Wanda. „Wstyd i wstydliwość jako afirmacja tajemnicy”. Jan Paweł II. Mężczyzna i niewiasta stworzyt ich. Chrystus odwotuje się do ,, poczatku”. O Jana Pawła II teologii ciała, Jan Paweł II naucza, t. 4, Redakcja Wydawnictw KUL, 1981, ss. 203-215.

Sawicki, Stefan, [głos w dyskusji w tomie:] Jan Paweł II. „Familiaris consortio”. Tekst i komentarze, Jan Paweł II naucza, t. 8, red. Tadeusz Styczeń, Redakcja Wydawnictw Katolickiego Uniwersytetu Lubelskiego, 1987, ss. 282-283.

Styczeń, Tadeusz. „Ciało jako «znak obrazu Stwórcy»”. Jan Paweł II. Mężczyzną i niewiastą stworzyt ich. Chrystus odwoluje się do „poczatku”. O Jana Pawła II teologii ciała, Jan Paweł II naucza, t. 4, Redakcja Wydawnictw KUL, 1981, ss. 85-138.

Styczeń, Tadeusz. „Istota więzi małżeńskiej w perspektywie filozoficzno-teologicznej”. Jan Paweł II. „Familiaris consortio”. Tekst i komentarze, Jan Paweł II naucza, t. 8, red. Tadeusz Styczeń, Redakcja Wydawnictw Katolickiego Uniwersytetu Lubelskiego, 1987, ss. 123-142. 


\section{KOBIETA W TWÓRCZOŚCI KAROLA WOJTYŁY - JANA PAWŁA II}

Streszczenie

Artykuł składa się z dwóch części. Część pierwsza dotyczy myślowego dorobku Papieża. Stanowi on kontekst autorski, niezbędny do analiz papieskich medytacji poetyckich, które są zamieszczone w części drugiej. Kontekst tworzą wypowiedzi z początkowego okresu pontyfikatu, które dla papieskiego nauczania o kobiecie są z pewnością najważniejsze. Mowa o edycji Jan Paweł II naucza - t. 1: Mężczyzna i niewiasta stworzyt ich. Chrystus odwotuje się do „,początku”. O Jana Pawła II teologii ciata, t. 4 tejże edycji: Sakrament oraz t. 8: Familiaris consortio, ponadto list apostolski Mulieris dignitatem. Te właśnie teksty stanowią właściwe zaplecze do badania papieskiego dorobku poetyckiego, gdyż podobnie jak poezja Jana Pawła II, ujmują kobietę w kategoriach metafizycznych, duchowych, Boskich. Takiej bazy interpretacyjnej nie zapewnia natomiast feminizm, ani nawet projekt nowego feminizmu Jana Pawła II, którego główną i chwalebną troską było przywracanie osobowej godności kobiety w wymiarze społecznym. Najistotniejsze ujęcia kobiety w papieskim nauczaniu nawiązują do Księgi Rodzaju, do opisów stworzenia człowieka - kobiety i mężczyzny, którzy stają się, mówiąc słowami Ojca Świętego, jednym ciałem, jednym sercem i jednym duchem. Tylko w tym paradygmacie, w „sakramencie stworzenia” (w jedności z mężczyzną) kobieta osiąga najwyższy status w wymiarze metafizycznym i personalistycznym. Znajduje to potwierdzenie w medytacji części drugiej Tryptyku rzymskiego. Jednak uniwersalność tego antropologicznego paradygmatu sprawia, że stosuje się on także do innych tekstów, których bohaterkami są same kobiety. Mowa o Magdalenie, Samarytance, Weronice czy dziewczynie zawiedzionej w miłości. Opracowanie obecne ogranicza się do poezji. Niewątpliwie bardzo istotna dla podejmowanej tu problematyki kobiety, interpretacja dramatu Przed sklepem jubilera stanie się przedmiotem odrębnego opracowania.

Słowa kluczowe: kobieta; mężczyzna; medytacja; „sakrament stworzenia”; osoba; podobieństwo Boże

\section{WOMEN IN THE WORKS OF KAROL WOJTYŁA / JOHN PAUL II}

\section{Sum mary}

This article consists of two parts. The first part focuses on the thoughts of the Pope, which we can treat as the author's context and which is necessary for analysing the papal poetic meditations. The analyses are included in the second part. The context is made up of statements from the early period of the pontificate, which should be considered the most important in the teachings of the Holy Father about women. I am referring here to the following editions of John Paul II's teachings: Vol. 1: He created man and woman. Christ refers to the "origin": John Paul II's theology of the body, Vol. 4: The Sacrament and Vol. 8: Familiaris Consortio: On the Role of the Christian Family in the Modern World, as well as the apostolic letter Mulieris Dignitatem: On the Dignity and Vocation of Women on the Occasion of the Marian Year. The aforementioned texts are the relevant basis for studying the papal poetic output, because, like the poetry of John Paul II, they capture woman in the metaphysical, spiritual and divine categories. Such an interpretational basis is not provided by feminism or even John Paul II's project of new feminism, whose main and laudable concern was to restore woman's personal dignity in the social dimension. The most important views on women in the papal teaching refer to the Book of Genesis, to the descriptions of the creation of the human being - a woman and a man who become, in the words of the Holy Father, one body, one heart and one spirit. It is in this paradigm, in the "sacrament of creation" (in union with a man) that a woman attains the highest status in the metaphysical and personalistic dimensions. This is confirmed by the meditation in Part 2 of the Roman Triptych. However, the universality of this anthropological paradigm means that it also applies 
to other texts whose protagonists are women themselves: Mary Magdalene, the Samaritan woman, Veronica, or the girl disappointed in love. The current study is limited to poetry. Undoubtedly, of great importance from the point of view of women's issues is the interpretation of the drama In front of the Jeweller's Shop: A Meditation on the Sacrament of Matrimony, Passing on Occasion into a Drama. This play will become the subject of a separate study.

Keywords: woman; man, meditation; "sacrament of creation"; person; God's image and likeness 